\title{
Добрый человек из Гонолулу(история спасения петроградских детей американским красным крестом)
}

\section{Olga Molkina}

Имя Райли Аллен ничего не скажет большинству жителей Петербурга. Однако есть немало семей, в которых память о человеке, его носившем, хранят уже многие годы. Ведь если бы не он, то, кто знает, существовали бы эти семьи вообще?

Человек по имени Райли Аллен ${ }^{1}$ жил и работал на далеких Гавайях, связь с которыми северной столицы просматривается весьма смутно.

Райли Аллен родился еще в позапрошлом веке. В 1918-ом, когда началась эта удивительная история, он был совсем молодым человеком, однако, уже занимал пост главного редактора самой известной в Гонолулу газеты «Honolulu Star Bulletin».

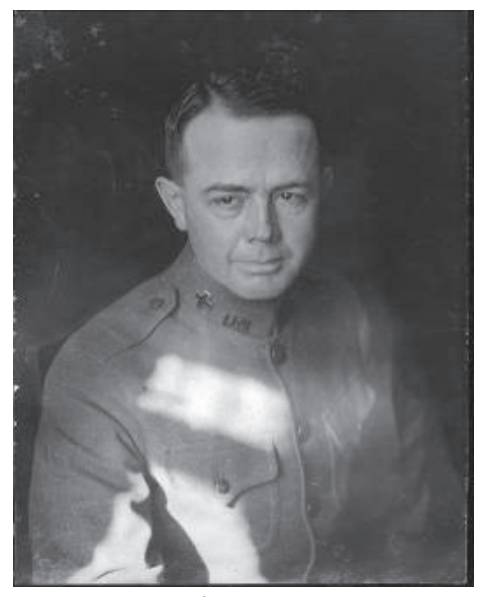

Райли Аллен в форме сотрудника Американского Красного Креста (АКК) Фото любезно предоставлено АКК (Вашингтон)
Блестящая карьера, хорошее положение и безбедная жизнь на цветущих островах бывшего Гавайского королевства, а теперь республики Гавайи, территория которой принадлежала США,-вот от чего неожиданно решил отказаться Аллен.

Что же заставило молодого человека принять такое странное решение?

Весна 1918 года не слишком улучшила настроение жителей Петрограда. Прошедшая зима унесла жизни и подорвала здоровье огромного числа горожан. Голод, холод, разруха и совершенно неопределенная политическая ситуация-следствия войны, буржуазной революции и государственного переворота ${ }^{2}$, совершенного большевиками-превратили некогда блестящую столицу огромной империи в

1 Райли Харрис Аллен (Railey Harris Allen) (1884-1966)—журналист, редактор, главный редактор газеты «Honolulu Star Bulletin» (1912-1960) с перерывом для участия в работе Миссии Американского Красного Креста в России (1918-1921).

2 Историки продолжают спорить о том, как называть события октября 1917 года в России: переворот или революция. Автору всегда был ближе термин «переворот», 


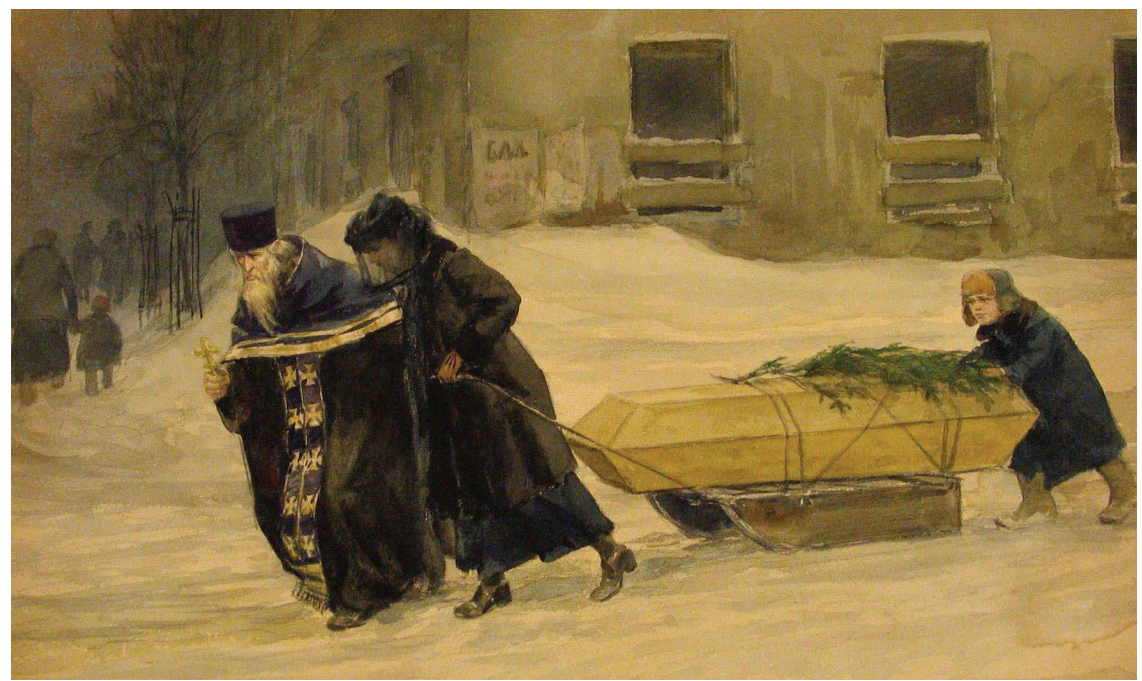

Зима 1918 г. в Петрограде. Рисунок художника Ивана Владимирова «В последний путь»

умирающий город, жизнь в котором становилась все более невыносимой. Особенно страдали дети и подростки, которые не могли нормально расти и формироваться без элементарных продуктов питания. Надо было что-то предпринимать для их спасения.

Еще в начале Первой мировой войны партия кадетов вместе с либеральными помещиками и буржуазией организовала так называемый Всероссийский Союз Городов, который занимался в основном гуманитарной помощью больным и раненым солдатам и беженцам с оккупированных территорий, устройством и оборудованием госпиталей и санитарных поездов, закупкой медикаментов и другими насущными проблемами военного времени. Союз существовал за счет частного капитала и пожертвований граждан.

Союз Городов, поддержавший Февральскую революцию, не приветствовал события Октября 1917 года . Новая власть вскоре ответила ему полной взаимностью, и Декретом от 9 января 1918 года комитеты Союза Городов, а также Красного Креста были упразднены, а их имущество и финансы национализированы ${ }^{3}$.

Однако столь мощные и за годы войны разросшиеся организации не могли в один день прекратить свое существование. Деятельность на местах продолжалась еще некоторое время. С 1920 года Союз Городов осуществлял свою деятельность в эмиграции, где занимался помощью детям беженцев и организацией в сфере образования.

правомерность которого отстаивает в частности Ричард Пайпс в своей книге «Русская революция. (The Russian Revolution by Richard Pipes).

3 Декрет от 9 января 1918 года

О передаче имущества и капиталов учреждений Красного Креста и Всероссийского Союза Городов в государственную собственность. Библиотека нормативно-правовых актов Союза Советских Социалистических Республик. www/libussr.ru. 


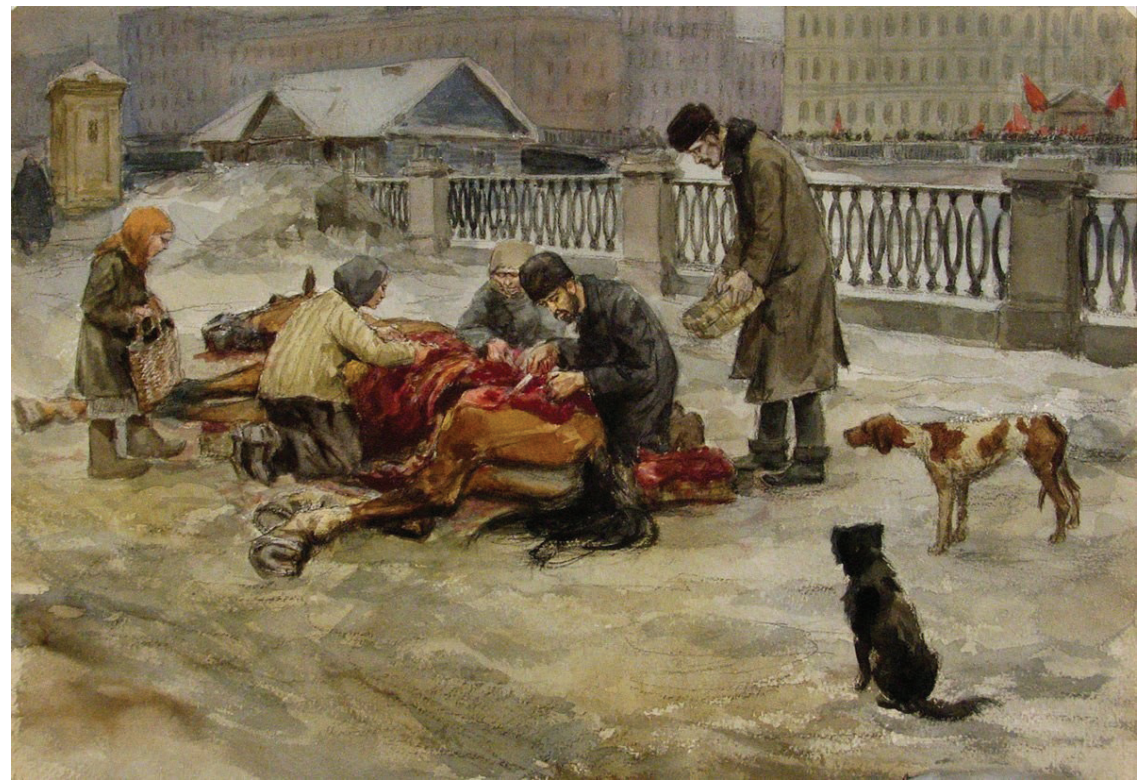

Зима 1918 г. в Петрограде. Рисунок художника Ивана Владимирова «Голод»

Поэтому именно Союз Городов выступил с инициативой, которую вынужден был поддержать Народный комиссариат просвещения РСФСР (Наркомпрос), вновь созданный взамен предшествующего ведомства - Министерства народного просвещения. Было принято решение эвакуировать как можно больше петроградских детей в так называемые питающие губернии, где за летние месяцы ребята могли бы подкормиться и окрепнуть. Родители детей и подростков с радостью восприняли сообщение о наборе детей в так называемые Детские летние питательные колонии и внесли посильную плату за три летних месяца пребывания в них.

Немало детей было отправлено в разные районы России и Украины в составе таких колоний, и впоследствии большинство из них благополучно вернулись в Петроград к новому учебному году.

Но двум группам юных петроградцев общим числом почти 1000 человек суждены были удивительные приключения.

Представители Союза Городов уже ранней весной сумели договориться о предоставлении помещений для детей из Петрограда на Урале и в Сибири.

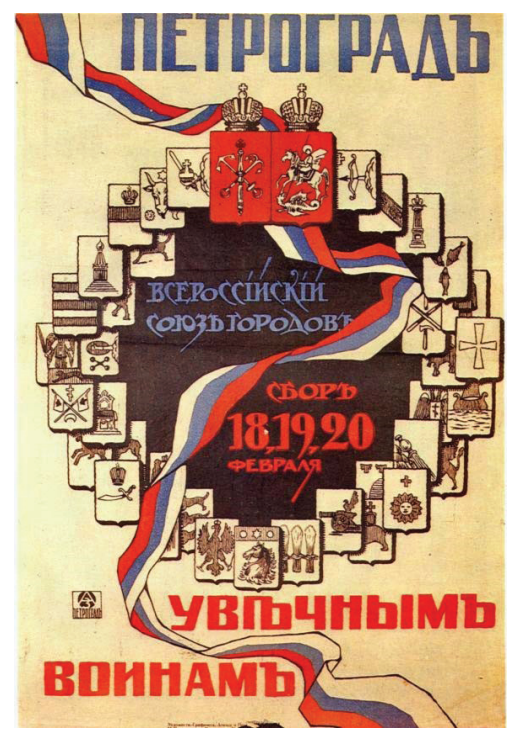

Плакат Всероссийского Союза Городов 


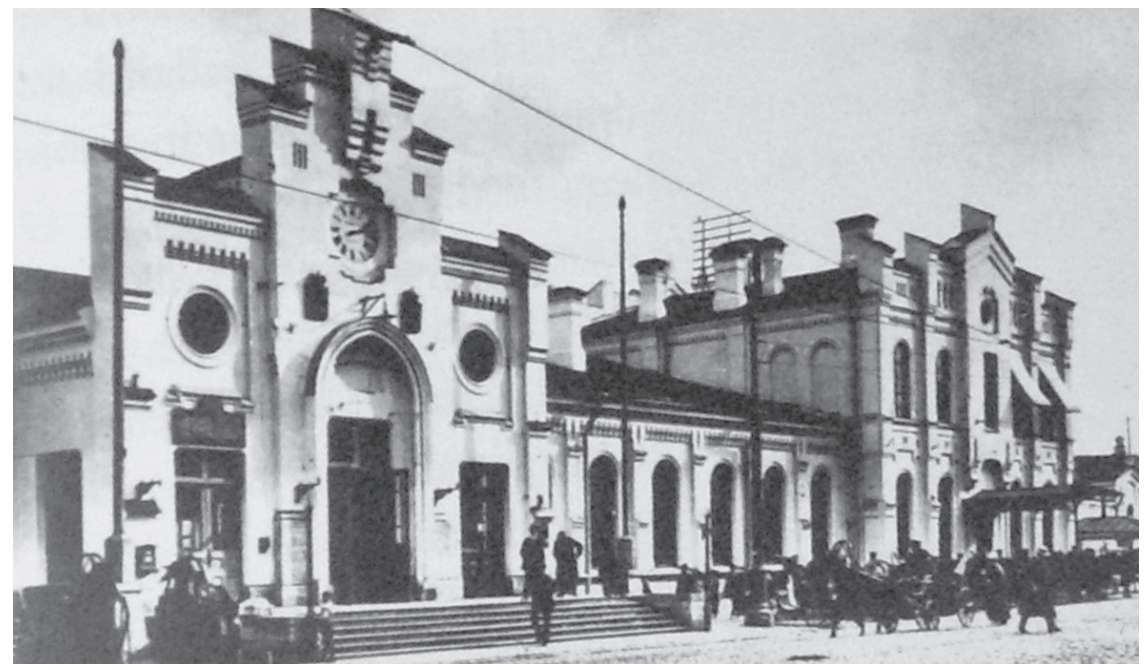

Финляндский вокзал в Петрограде. Фотография начала XX века

Первая группа в количестве 475 ребят разного возраста выехала с Финляндского вокзала (важное обстоятельство для этой истории) на санитарном поезде в город Миасс 18 мая. Вторая группа неделей позже выехала в город Петропавловск (сейчас Казахстан). В ней было еще 420 детей.

Вот что написано в отчете петроградской областной организации Союза Городов в разделе, посвященном продовольственной помощи.

«Несмотря на многие препятствия, как в центре, так и на местах, несколько <.. > колоний приготовлены и первый санитарный поезд с 475 детьми отбыл из Петрограда 5/18 мая в Миасс, Оренбургской губ. Второй санитарный поезд с 420 детьми отбыл из Петрограда 12/25 мая в Петропавловск, где организована своя многолюдная колония... За этими поездами последует значительное количество поездов, вероятно, до 15-ти. Проезд в оба конца, содержание, педагогический надзор, медицинская помощь каждого ребенка обходятся в 75 р. Более состоятельные родители вносят высшую сумму, чем предоставляют возможность Областному Комитету эвакуировать детей неимущих родителей. Со своей стороны Областной Комитет широко организует в районах сбор-особый фонд спасения детей, благодаря которому, можно надеяться, будет возможность эвакуировать значительное количество детей неимущих родителей... Для того, чтобы убедиться, насколько это дело не только отвечает насущной потребности Петроградского населения, но является действительно спасительным средством для детей, надо было присутствовать при отправке поезда - видеть радостно возбужденные лица детей, размещенных со всеми удобствами в санитарном поезде, и слушать их восторженные и удивленные возгласы за ужином: «Каша!...С маслом!...» При прощании с родителями из 475 ребят заплакала только одна девочка». ${ }^{4}$

4 Издание Петроградской Областной Организации Всероссийского Союза Городов № 6-7 за апрель-июнь 1918 г. С.9. 
Проводив сыновей и дочерей на каникулы, родители, отчаявшиеся уже накормить и спасти их в Петрограде, вздохнули с облегчением и стали ждать писем от своих чад.

Однако радость их была преждевременной.

Не успел санитарный поезд № 101 после недели в пути приблизиться к Челябинску, как его пассажиры неожиданно почувствовали резкий толчок, и поезд остановился буквально в чистом поле. Захлопали двери вагонов, раздались незнакомые голоса, и в поезд вошли солдаты в форме и с оружием нерусского образца. Говорили они на странном языке, некоторые слова которого были похожи на русские, но все равно ничего понять испуганные ребята и их воспитатели не могли.

А случилось вот что.

Знаменитый Чехословацкий легион, который состоял из чехов, словаков, венгров и австрийцев, перешедших на сторону России, и который успешно воевал вместе с русской армией против Германии, неожиданно устроил мятеж и захватил ряд городов и станций на Транссибирской магистрали. Что заставило командование Легиона пойти на такой шаг в конце войны, когда большинство из них уже только и думали о возвращении домой, во вновь образованную Чехословакию и в другие районы бывшей Австро-Венгерской империи? Долгие годы подробности тех событий были мало изучены. Сегодня мы знаем, что направлявшиеся к Тихому океану эшелоны с чехами были разоружены большевиками по приказу Л.Троцкого. Стерпеть такую обиду чехи не смогли. Вспыхнули мятежи, спровоцированные разными незначительными поводами, но фактически обусловленные невозможностью смириться с приказом, затрагивавшим права и гордость людей, которые честно отдавали свои силы, свой труд, а многие и жизнь, помогая своим славянским братьям бороться с ненавистным врагом - Германией.

На волне мятежа, Белая армия также собралась с силами и установила свою власть во многих городах Сибири и Урала.

Так началась гражданская война.

И так начались каникулы для почти тысячи человек детей и взрослых, попавших в эту круговерть политических и военных событий из далекого голодного Петрограда.

Воспитателям удалось уладить вопрос о продвижении поездов с детьми к местам назначения. Правда, первоначальный маршрут второго состава с петроградскими детьми, прибывшего на Урал неделей позднее, пришлось изменить, так как путь до Петропавловска был небезопасен. Однако удалось договориться с местными властями о предоставлении детям помещений в бывшем санатории Курьи, расположенном в живописном месте в Екатеринбургской губернии. Колонисты из первого состава, того самого поезда №101, разместились, как и планировалось в городе Миасс под Челябинском.

Лето на Урале обычно бывает теплое, сухое. Так было и в этот раз. И петроградские ребята, которые уже привыкли называть себя «колонистами» (а как еще назовешь членов детской летней питательной колонии?), прекрасно проводили каникулы, наслаждаясь свободой, теплом, относительной сыто- 


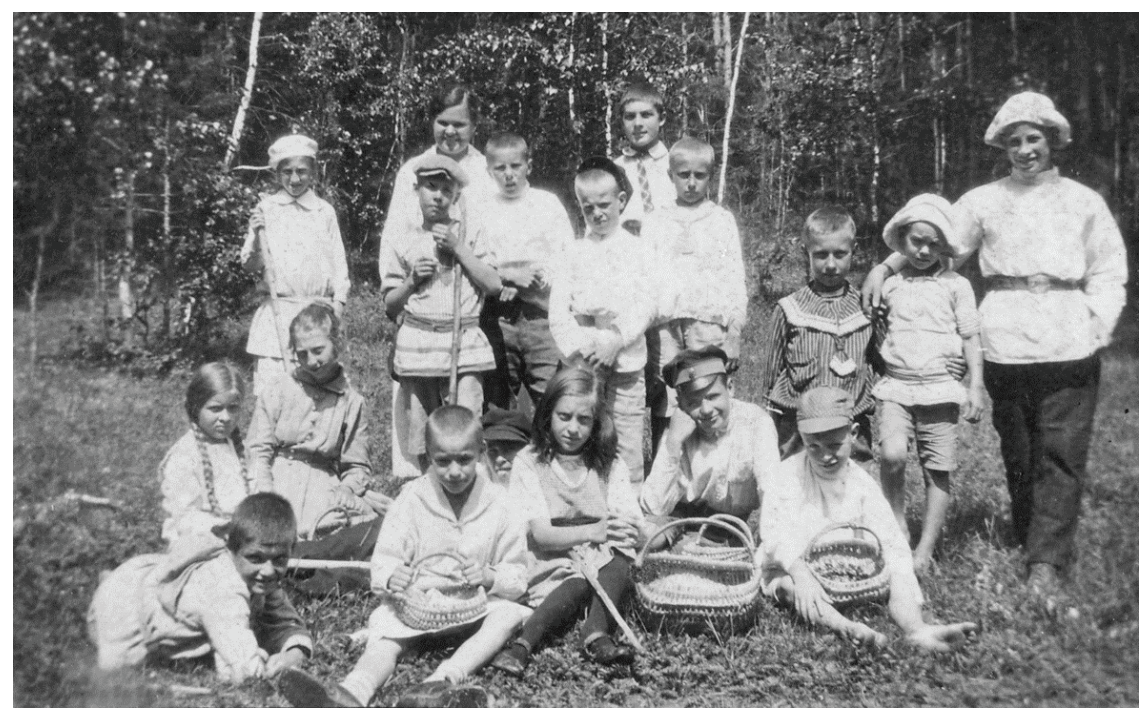

Группа колонистов среднего возраста на экскурсии в предгорьях Урала.

стью и интереснейшими экскурсиями и походами в горы и к великолепным озерам, которых немало в этих местах.

Но время шло. Приближался сентябрь, а вместе с ним и первые проблемы. Деньги на пропитание и содержание колонистов стремительно обесценивались, и вскоре это стало очень заметно по все более скудному меню. И это бы еще ничего - к полуголодной жизни привыкли за последнюю зиму в Петрограде. Но не следует забывать о том, что кругом, а часто и в непосредственной близости шла страшная братоубийственная война. И все чаще ребята становились свидетелями ужасных событий - перестрелок, гибели от пуль, жестоких казней через расстрел и повешение. Причем и белые, и красные, и другие неведомые силы, временами появлявшиеся перед окнами помещения, где жили колонисты, вели себя одинаково безжалостно по отношению к тем, кого на разных основаниях определили своими врагами.

«Однажды летним солнечным вечером мимо нашей казармы, находившейся на самой окраине города, у леса, проходила группа изможденных полураздетых людей, окруженных со всех сторон вооруженной охраной. То были «красные», попавшие в руки «белых».

Один из них, совсем молодой парень, едва плелся позади всех. И вот солдат-охранник с силой ударил его прикладом винтовки в спину. От этого неожиданного толчка все тело его изогнулось волной, и он, с трудом удерживаясь на ногах, с ужасом смотрел на своих мучителей...

Всю эту группу подвели к опушке леса и, окружив кольцом охраны, накинули петли на шеи и тут же повесили на сучьях деревьев на виду у всех...

И несколько дней из своих окон мы видели качающиеся на ветру почерневшие трупы...

И несколько дней там толпились местные бородатые крестьяне. Они тихо переговаривались между собой и что-то обдумывали.. 
И долго еще были слышны там вопли и причитания несчастных жен и матерей...» ${ }^{5}$

Не слишком церемонились воюющие стороны и с детьми. Время от времени то одни, то другие заходили в помещения, где жили ребята, протыкали штыками матрасы, набитые соломой, что-то искали, заглядывая под койки и пугая младших колонистов своим грозным видом.

Воспитатели и учителя были в отчаянии. Опасность становилась все более очевидной. К тому же деньги и продовольствие заканчивались, теплой одежды не было, а возвращение назад через линию фронта казалось все менее реальной задачей.

Благодаря поддержке местных представительств Союза Городов и Красного Креста, а также помощи богатых благотворителей, имена которых, к сожалению, не сохранились в памяти колонистов, удалось продержаться до глубокой осени, хотя тяжелое положение с продуктами и жильем, заставило воспитателей рассредоточить колонистов, отправить их малыми группами в весьма отдаленные друг от друга города, поселки и казацкие станицы. Миасс, Тургояк, Троицк, станица Уйская, Ирбит, Тобольск, Томск, Тюмень, Петропавловск - вот далеко не полный список мест, где удалось разместить несколько сотен колонистов, которые уже привыкли к мысли о том, что дома они окажутся не скоро. Связь с родителями в далеком Петрограде тоже прервалась. Впереди была неизвестность.

Несмотря на все героические старания воспитателей, многие из которых остались верными своему долгу и разделили с детьми все трудности, положение в некоторых группах было катастрофическим. Ребята постарше ходили на заработки к местным жителям, делали посильную, а иногда и непосильную работу в местных крестьянских хозяйствах, чтобы заработать пропитание для себя и для самых маленьких колонистов, младшему из которых - ребенку одного из воспитателей - не было и трех лет. Те, кто не находили себе применение, повадились попрошайничать, а то и воровать еду на базаре, к ужасу старавшихся сохранить достоинство педагогов. Управлять подростками, особенно мальчиками, в такой ситуации становилось все сложнее.

Помощь и спасение совершенно неожиданно пришли зимой 1918-19 гг.,, а чудом явившиеся спасители плохо говорили по-русски.

Но вернемся немного назад. На рассвете 30 ноября 1918 года американский гражданин Райли Аллен стоял на палубе японского судна «Шиньё Мару», которое приближалось к городу Владивостоку. Вот она - далекая и непонятная Россия, где ему предстояло работать в качестве волонтера Американского Красного Креста (АКК), деятельность которого на территории России была поистине грандиозна. «18 госпиталей на 6596 коек были в распоряжении этой международной организации. В этих госпиталях работали

5 Воспоминания бывшего колониста Ю.Н.Заводчикова. Рукопись. Семейный архив автора. 
56 американских врачей и 34 врача других национальностей, 182 американских сестры милосердия, 350 русских сестер и санитарок, 15 японских и 13 китайских сестер милосердия.

Из Владивостока было отправлено 33 поезда по 23 вагона в каждом. Они везли 8 тысяч тонн грузов, прибывших на 30 кораблях из Америки и на 92 - из других стран-союзниц. Еда, одежда, медикаменты были распределены среди 587000 мужчин, 387000 женщин и 775000 детей». ${ }^{6}$

«Общие расходы [Сибирской Миссии Американского Красного Креста] в Сибири, включая стоимость пожертвованных расходных материалов и оборудования, составила сумму более 23 миллионов долларов.» ${ }^{7}$

Когда Аллен в далеком Гонолулу принимал решение бросить все и отправиться в Россию, он не мог знать этих впечатляющих цифр. Но журналистское чутье подсказывало ему, что в огромной неведомой стране России его ждут великие дела.

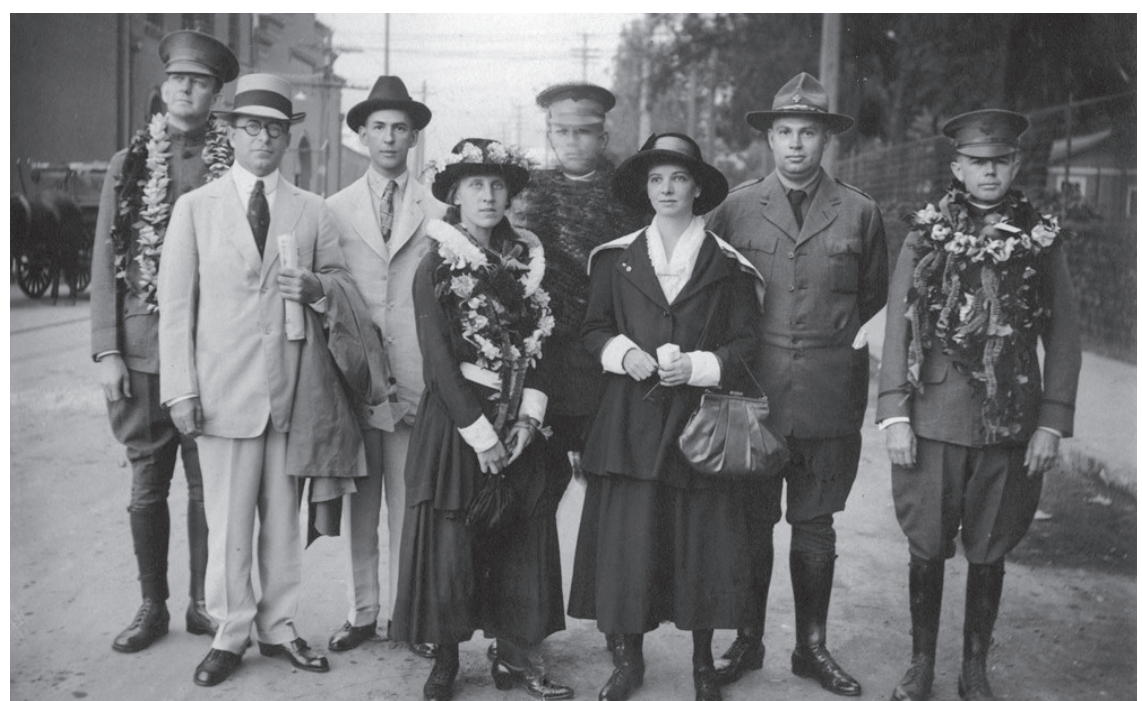

Волонтеры-гавайцы. 1918 г. Первый справа Райли Аллен. Фото любезно предоставлено АКК (Вашингтон)

Начав с должности пресс-секретаря, добросовестный и трудолюбивый Аллен вскоре стал помощником главы всей Сибирской миссии Американского Красного Креста доктора Рудольфа Тойслера ${ }^{8}$.

${ }^{6}$ The Wild Children of the Urals. By Floyd Miller. New York, 1965. p.30. Перевод автора.

7 The American Red Cross. A History by Foster Rhea Dulles. Harper \& Brothers publishers, New York, 1950 p. 210. Перевод автора.

8 Рудольф Тойслер (Rudolf Bolling Teusler) (1876-1934)-американский врач, миссионер, основатель Госпиталя Святого Луки в Токио. Руководитель Миссии Американского Красного Креста во Владивостоке (1918-1919 гг.). 


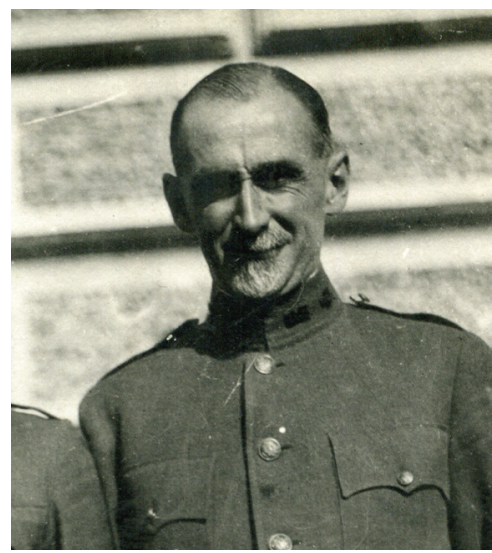

Доктор Рудольф Б.Тойслер

Так случилось, что прибытие Аллена в Россию совпало с исключительно важными политическими событиями. Буквально в тот же день, когда Аллен сошел с борта «Шиньё Мару» (Shinyō Maru) на российскую землю, военный и морской министр вице-адмирал Александр Васильевич Колчак был произведен в адмиралы. При этом были опубликованы следующие постановления:

«Вследствие чрезвычайных событий, прервавших деятельность Временного Всероссийского Правительства, Совет министров, с согласия наличных членов Временного Всероссийского правительства, постановил: принять на себя всю полноту верховной государственной власти» 9 .

«Ввиду тяжелого положения государства и необходимости сосредоточить всю полноту Верховной Власти в одних руках, Совет министров постановил: передать временно осуществление верховной государственной власти адмиралу Александру Васильевичу Колчаку, присвоив ему звание Верховного правителя» ${ }^{10}$.

Аллен не очень хорошо знал, кто такой этот русский адмирал, чье имя вызывало столь разноречивые чувства у разных людей. Но сейчас для него важно было заручиться поддержкой действующей власти для осуществления своих почти фантастических планов, связанных со сведениями, полученными им от представителей АКК, работавших на территории Сибири. Они рассказали Аллену весьма странную и противоречивую историю о том, что в нескольких местах на Южном Урале и в Сибири они встречали группы плохо одетых и полуголодных русских детей, которые якобы прибыли из Петрограда и оказались в бедственном положении ${ }^{11}$. Аллен, не раздумывая, решил, что Красный Крест не может остаться в стороне, и начал действовать.

Получив добро у своего непосредственного начальника доктора Рудольфа Тойслера, Аллен отправился на прием к одному из министров колчаковского правительства. Однако в голове министра не оказалось места для гран-

9 Цит.по: В.Краснов. Колчак. И жизнь, и смерть за Россию.ОЛМА-ПРЕСС, 2000. т.2. С.10.

${ }_{10}^{10}$ Там же.

${ }^{11}$ Сегодня, благодаря усилиям частных исследователей-потомков участников событий нам известно, что петроградские дети попали в сферу внимания АКК не случайно. Этому во многом способствовал представитель шведского Красного Креста пастор Сарве, а также председатель родительского комитета колонистов Валерий Львович Альбрехт В начале зимы 1918-19гг. они с огромным трудом добрались до мест расселения колонистов в Сибири и, поняв, что организовать отправку детей в Петроград невозможно, сумели договориться непосредственно с представителями АКК о передаче детей под их опеку. 
диозных планов спасения своих юных соотечественников. Она была занята, по его мнению, несоизмеримо более серьезными проблемами, чем какие-то мифические полуголодные и полураздетые дети, невесть как оказавшиеся вдали от своих родителей, которым и следовало бы отвечать за их благополучие.

Аллен быстро понял, что обратился не по адресу. Его, гражданина другой страны, эти русские дети, которых он еще никогда не видел, волновали значительно больше, чем господина российского министра. И Аллен стал искать поддержки уже у своих соотечественников.

В Сибири и на Дальнем востоке консервативные русские относились к американскому присутствию если не враждебно, то с большим подозрением, чему способствовала пропаганда в печати. Американцев обвиняли в скрытом сочувствии большевикам. У союзников американцы тоже не вызывали особого восторга. Обстановка была напряженная, и для поддержания порядка и осуществления нормальной деятельности в соответствии с меморандумом Вильсона нужен был человек с трезвым умом и твердым характером. Таким человеком и был командующий Американским Экспедиционным Корпусом в Сибири генерал Грейвс ${ }^{12}$. Меморандум Вильсона, в котором говорилось о невмешательстве во внутренние дела России, Грейвс считал основополагающим документом. Деятельность АКК вызывала его раздражение, поскольку он был уверен, что помощь, которую АКК оказывал, например, чехам, была помощью тем, кто явно вмешивался во внутренние дела России. Ведь как бы ни оценивали в Европе и за океаном Брестский мир, война для России уже закончилась, и поддержка иностранными армиями одной из сторон, участвующих теперь уже в войне гражданской, формально была явным вмешательством в российские внутренние дела.

Через несколько лет в своей книге «Американская авантюра в Сибири» ${ }^{13}$ генерал Грэйвс с неприязнью писал о докторе Тойслере, который организовал работу АКК в Сибири и во Владивостоке и отправлял продовольственные и другие товары в Омск не для раздачи их российским гражданам, а для снабжения штаба и армии Колчака.

В ответ на претензии генерала Грэйвса доктор Тойслер не без гордости заявлял, что АКК оказывает помощь всем нуждающимся, независимо от их политических пристрастий и принадлежности к той или иной воюющей стороне.

Оба-генерал и доктор - искренне не сомневались каждый в собственной правоте и готовы были отстаивать свои принципы. Вообще они во многом походили друг на друга. И тот и другой были немногословны, тверды в своих решениях и трудно шли на компромисс в том, что касалось исполнения служебного долга. Конечно, два таких человека находились в посто-

${ }^{12}$ Уильям Сидней Грейвс ( William Sidney Graves, 1865-1940)-американский генерал, командовавший американскими оккупационными силами на Дальнем востоке и в Сибири во время гражданской войны в России.

${ }^{13}$ America's Syberian Adventure (1918-1920) by General William S. Graves. 
янной конфронтации друг с другом. Поэтому оба в душе удивились, когда неожиданно нашли общий язык по вопросу, к обсуждению которого подтолкнул их Аллен.

Генерал Грэйвс пообещал доктору Тойслеру, что, если дети действительно существуют и будут найдены и собраны вместе, то вооруженная охрана для перевозки грузов и, если понадобится, самих детей будет непременно обеспечена. Предполагалось, что все заботы о питании, одежде и медикаментах для детей возьмет на себя АКК.

Это была первая победа Аллена в борьбе за спасение чужих русских детей, которых он еще ни разу не видел.

Посланники АКК, отправленные Алленом во все известные пункты, где находились петроградские колонисты, добросовестно справились со своим заданием. Вместе с ними прибыли грузы, состоявшие из столь необходимых детям и воспитателям продовольствия, медикаментов, тканей для пошива одежды, предметов личной гигиены и даже учебников и игрушек. Более того, старшие мальчики одной из групп, получили поистине царский подарок - музыкальные инструменты. Одаренные ребята, а их было немало среди колонистов, с восторгом приняли идею создать свой, колонистский оркестр. Ведь все колонисты, а особенно колонистки обожали не только хоровое пение, которым развлекались и даже иногда зарабатывали, но и танцы по субботам.

Жизнь колонистов под покровительством новых американских друзей потекла теперь совсем по-другому. Воспитатели тоже вздохнули свободнее, передав бразды правления американским коллегам.

Однако политические и военные события заставляли и тех, и других быть в постоянном напряжении. Наступление Красной армии, смена власти в отдельных населенных пунктах и невозможность отправить детей домой, в Петроград по железной дороге диктовали необходимость новых, нетривиальных решений.

И вот летом 1919 года несколько железнодорожных составов под усиленной охраной американских солдат уже везут почти девять сотен юных петроградцев и их воспитателей, которых удалось в короткое время собрать из всех городов и станиц, где они к тому времени оказались. Поезда неплохо оборудованы по меркам военного времени, ребята получают хорошее питание, включающее даже такие невиданные заморские деликатесы, как консервированные ананасы. Всем весело и интересно. Однако поезда почему-то идут не на запад, к Петрограду, а в противоположном направлении-к Тихому океану, в далекий город Владивосток, где с волнением ждет своих новых подопечных Райли Аллен.

Этот маршрут, по многим причинам признанный тогда единственно возможным, отдалил колонистов от родного города и от родителей на тысячи километров.

Почти целый год им предстояло прожить во Владивостоке и на острове Русский. И все это время они не получали никаких сведений о родных и 


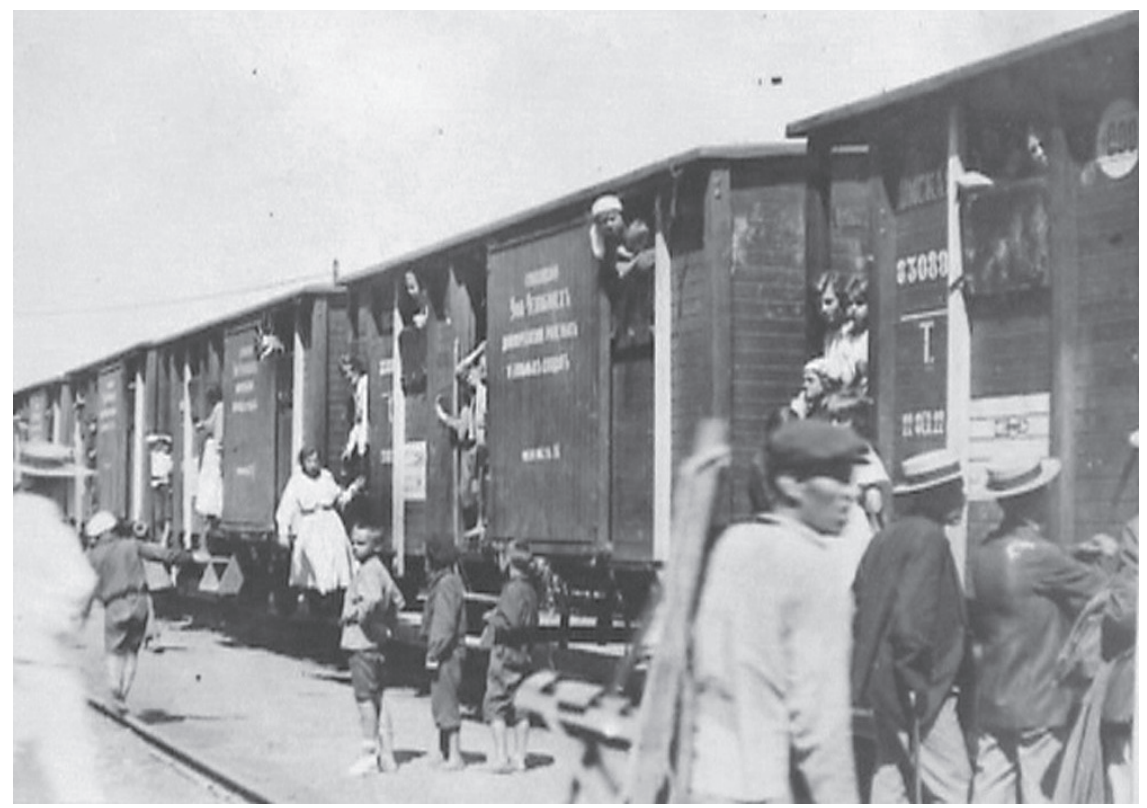

Поезд с колонистами на одной из станций Транссибирской магистрали

близких. Родители тоже практически ничего не знали о судьбах своих детей. Многие считали их пропавшими навсегда в бескрайних просторах воюющей страны. Скупые сведения о судьбе колонии, периодически появлявшиеся в советских источниках, были противоречивы и носили драматический характер. Американский Красный Крест обвиняли чуть ли не в захвате детей в заложники.

Тем временем жизнь во Владивостоке и на острове Русский шла своим чередом и была вовсе не плохой. Все были одеты и обуты, все получали необходимую медицинскую помощь, обо всех заботились, как могли, и сам Райли Аллен, ставший официально начальником колонии, и его замечательные помощники-сотрудники Американского Красного Креста, среди которых больше всех запомнились колонистам молодой менеджер .Бёрл Брэмхалл ( Burl Bramhall) и Ханна Кэмпбелл, которую все звали не иначе, как Мамаша Кэмпбелл. Ребята учились в местных гимназиях и реальных училищах, самые старшие мальчики даже поступили в институт, девушки-на курсы сестер милосердия. В дополнение к обычным школьным занятиям, которые велись по существовавшим в России программам, американцы занимались с ребятами английским языком, хотя нельзя сказать, что очень преуспели в этом благородном деле. Гораздо больше, чем зубрить английские слова, ребятам нравилось танцевать. Каждую субботу под звуки собственного оркестра, кружились красивые пары повзрослевших юношей и девушек. Как и положено, случались конфликты со взрослыми, ссоры между собой, проливались слезы обиды и неразделенной любви, мальчишки дрались и мирились, все давно привыкли к коллективной жизни вдали от семьи. Но каждый 
раз, когда кто-то из колонистов встречал Аллена, он не мог удержаться от вопроса: «Мистер Аллен, скажите, а когда нас отправят домой?» Вопрос этот тревожил и больших, и маленьких. Никто не мог даже представить себе, что останется здесь навсегда, как бы хороша и беззаботна ни была жизнь под крылом добрых американцев, тративших не только все силы своей души, но и колоссальные материальные средства на содержание такого количества детей и подростков.

К тому времени политическая ситуация серьезно изменилась. Власть адмирала Колчака пала, красные активно продвигались на восток. К концу зимы 1920 года стало ясно, что интервенция союзников в Сибирь не дала никаких результатов. Англия, а за ней и Франция эвакуировали большую часть своих вооруженных сил. Государственный Секретарь Соединенных Штатов готовил приказ о выводе американских войск под командованием генерала Грейвса из Владивостока. Лишь японцы не собирались выводить свои войска. Напротив, именно теперь наступил тот момент, когда они рассчитывали заполнить вакуум власти в регионе, образовавшийся в результате ухода союзников. К весне 1920 года расширение зоны, контролируемой японскими силами, привело к тому, что Транссибирская магистраль была полностью блокирована. Аллен, который сделал все возможное и невозможное, чтобы сформировать поезда с охраной для вывоза на запад петроградских детей, понял, что все его старания были напрасны.

1 апреля генерал Грейвс вывел свои войска из Владивостока, а 5 апреля японцы захватили город. Больше медлить было нельзя.

Контингент Миссии Красного Креста должен был, наконец, покинуть территорию России. Лишь одно препятствие для выполнения этого приказа было на пути у Аллена, давно уже заменившего на посту главы Миссии своего предшественника и друга доктора Тойслера. Этим препятствием были

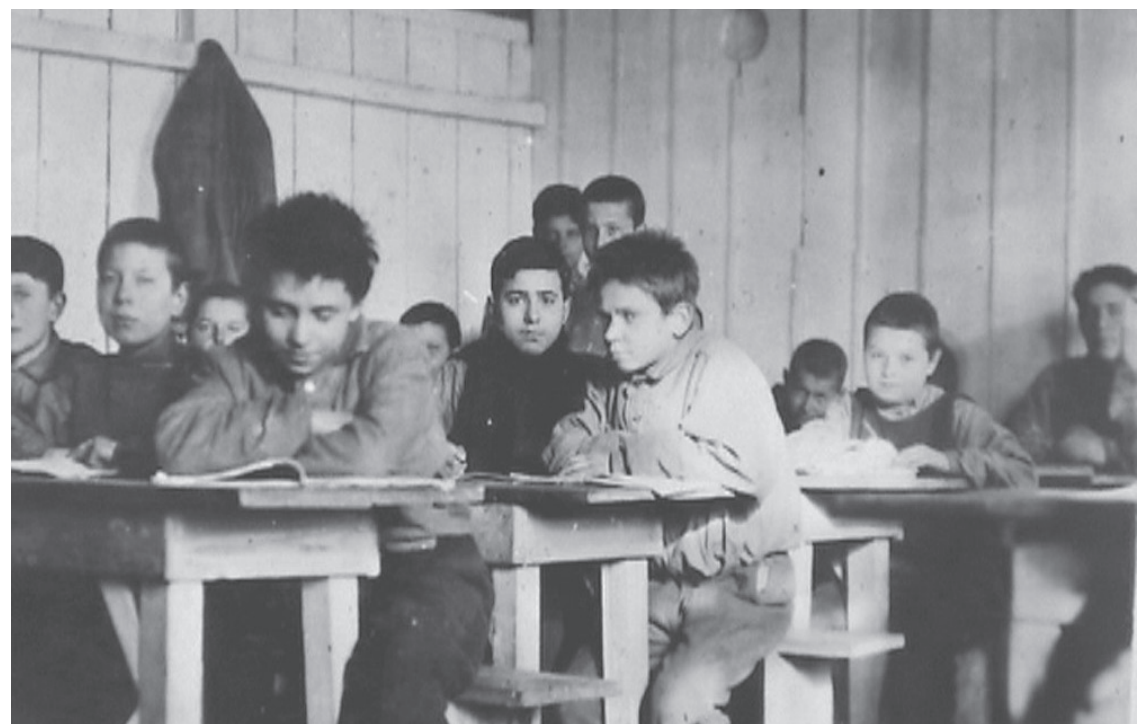

Колонисты на уроке в школе. Остров Русский. 1919 г. 
русские дети. Оставить их здесь на произвол судьбы без крыши над головой, без средств к существованию, без опеки, без охраны, без документов-об этом Аллен даже и не мыслил. Казалось, выхода не было. Но на одном из собраний сотрудников Аллен твердо и решительно заявил: «Мы должны увезти колонию из Владивостока!» Как это сделать, он еще не знал сам. Все усилия Аллена, направленные на поиски возможного места эвакуации детей, оказались бесполезными. Оставалось одно: взять их с собой в Соединенные Штаты, а уже оттуда переправить в Европу.

Однако было совершенно не ясно, как реализовать эту, уже совершенно фантастическую идею. Ни одна страна не пожелала предоставить свой транспорт для петроградских детей. У всех было полно неотложных перевозок, которые надо было осуществлять. Эвакуация людей-как военных, так и гражданских, отправка разнообразного имущества-все это требовало большого количества морского транспорта. Толпы граждан, стремившихся поскорее покинуть Россию, штурмом брали каждый борт.

И только в Японии, отношения с которой как у России, так и у Coeдиненных Штатов были весьма натянутыми, нашлась компания, готовая предоставить для фрахта сухогруз с красивым названием «Йомей Мару» и японской командой на борту. К тому были причины, которые можно кратко обозначить как роль личности. Этой личностью, сумевшей убедить хозяина компании Кацуда Гиндзиро ${ }^{14}$ стал доктор Тойслер, который к тому времени успел заработать себе отличную репутации в Японии, где давно уже занимался организацией здравоохранения.

Путешествие детей и женщин через два океана на обыкновенном сухогрузе-такого еще не было в истории. Затея Аллена многим казалась заведомой неудачей.

И, тем не менее, 13 июля 1920 года на борт сухогруза, переоборудованного за полтора месяца в не шикарное, но вполне пригодное для жизни пассажирское судно, один за одним поднялись более 800 мальчиков и девочек, их воспитатели, сотрудники и сотрудницы Американского Красного Креста, а также довольно большая группа бывших австро-венгерских военнопленных, направлявшихся к себе домой, в Европу и согласившихся выполнять по пути различные технические работы.

«Йомей Мару», на одной из труб которого был нарисован огромный красный крест на белом фоне, а на борту издалека читалась надпись “American Red Cross”, провожала разъяренная толпа военных и штатских людей, которые хотели покинуть Владивосток и шансы которых на это стремительно уменьшались с уходом каждого следующего судна.

Но юные путешественники поневоле не слишком интересовались тем, что остается за кормой их удивительного «Ноева ковчега». Мысли их были устремлены вперед, к новым приключениям.

Первой страной, гостеприимно принявшей безбилетных и беспаспортных петроградцев, была Япония. Как бы ни складывались политические и

${ }^{14}$ Кацуда Гиндзиро (1873-1952)—-владелец судоходной компании Katsuda Steamship Company, Ltd в г.Кобо, Япония. 


\section{I}

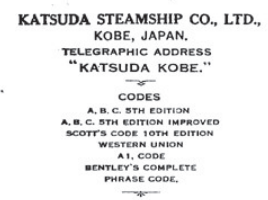

\section{TIME GHARTER.}

KOBE, Aune I 1920

\section{S.S. "Yomei-marv" "}

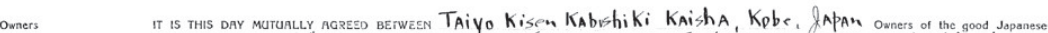

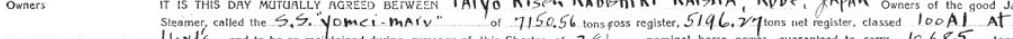
Description of Lloyd's and to be so maihtained duriag currency of this Charter, of 281 nominal horse power. guaranteed to carry 10685 tons dead-
Steames

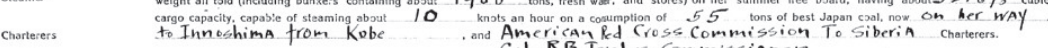
Period

Port of Delivery 1. That the said Oxners agres to let, and the said Charterers agree to tis the said Steamer for the term of Three calcinder calendar months from the day (such day not to be Sunday or a legal holiday and in no case before noon fin the said Steamer is deiliveres ant placed at the disposal of the Charteers, and zer written notice has been given between the hours of 9 a.m. and 6 p.m., or between of a.m. and 2 p.m. If on saturday at. In ho 0 himi. in such and every way fitted for the service (with he: compienznt of officers and crew) tobe employed in such laxtul tades, between poits of places within the following limits:- General Trading Excluding Bering Sea, Arctic Ocean, Coast of Iceland, and horts of Bergen, Norway, As well as Gult of St. Lawrenc- Coast of Novascotia, Baltic Sea trom Oct. I to Aprill of the following year exeept at Charterers risk, whik SeA, Black Sea. Str. of Magellan and coast of Alaska. That the said steaner is not to carryduring the period covering from sept I April I of the following year, full eargo of eilker grins or Lumber trom horth atlantic portstithe united Kingdom or Continental (Eluropeas) polrts, also that it is not to carry as sargo any India. coal for the period covering from the mar $I$ to june 30 inclusive.

2. That the Owners shall provide and pay for all provislons, and wages a the Captain, officers, and crew, and for the consulas charges pertaining to the Steamer's personnel above mentioned: shall pay for the insurance of the Steame; also for all the deck, engineroom, and other necessary stores; and to maintain

Фрагмент договора о фрахте сухогруза «Йомей Мару». Национальный архив США.

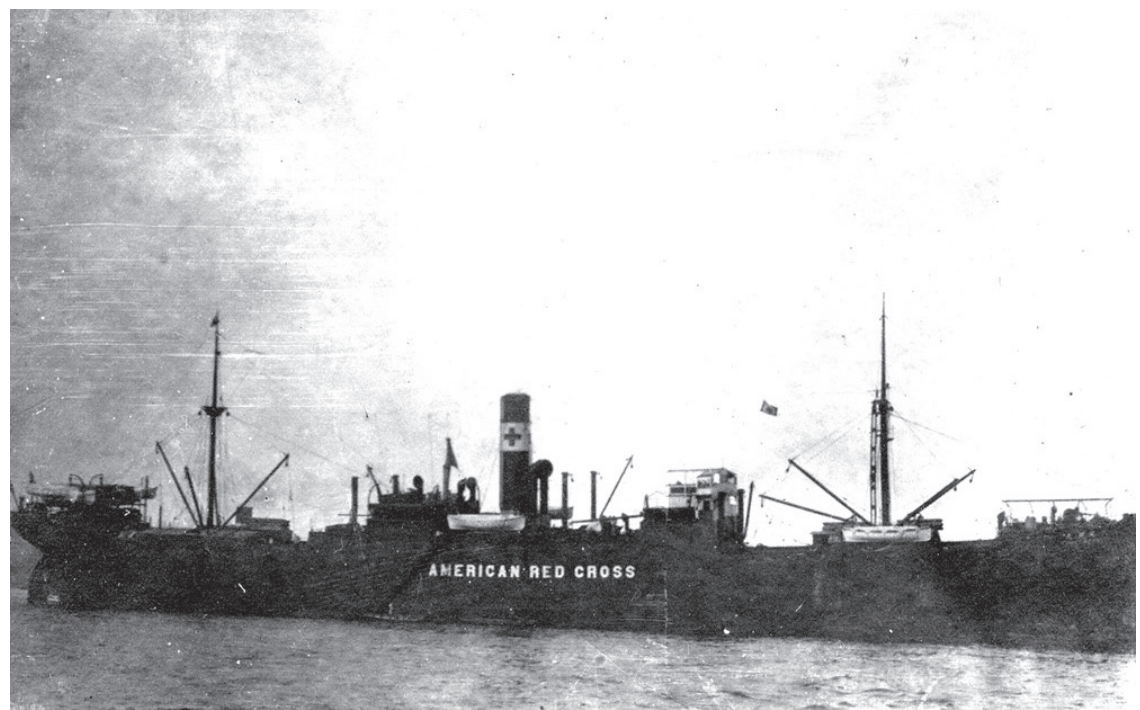

Японский сухогруз «Йомей Мару».Владивосток, июль 1920 г.

военные отношения между Японией и Россией в последние годы, это никак не сказалось на детях. Они были желанными гостями, и провели в небольшом порту Муроран на острове Хоккайдо долгий и счастливый день. Заваленные гостинцами и сувенирами, переполненные впечатлениями, покидали колонисты берега Японии. 


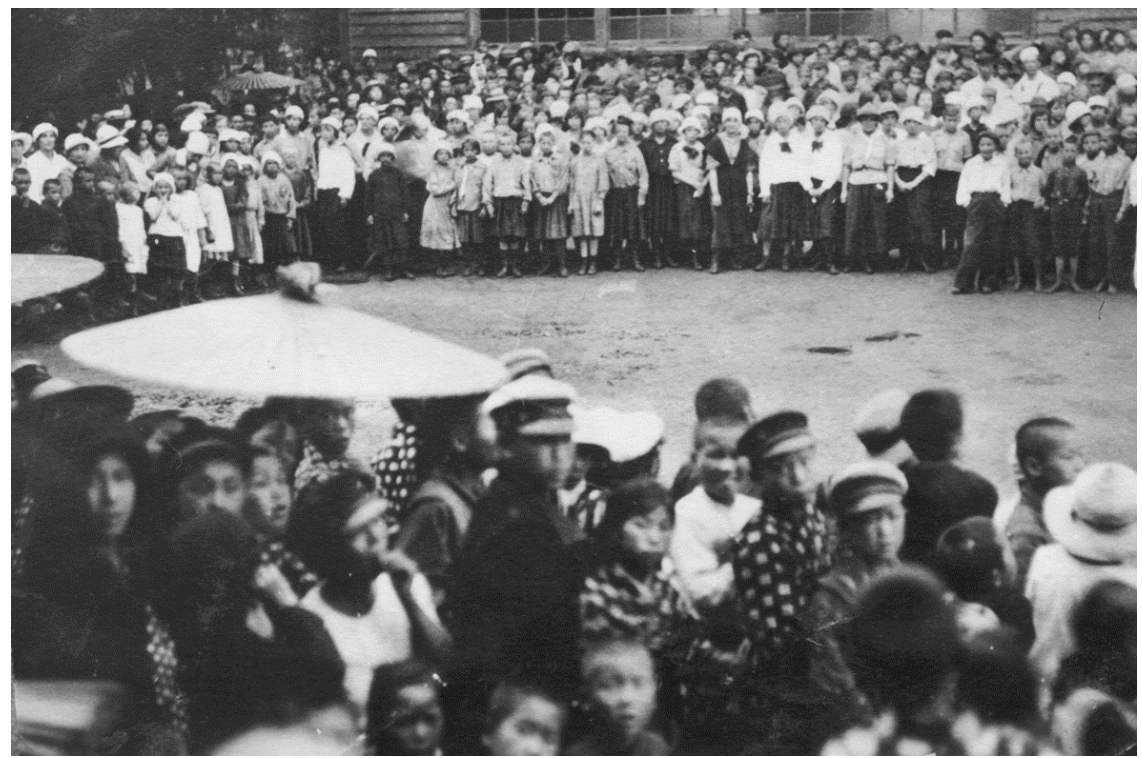

Петроградские колонисты в гостях у японских школьников. Порт Муроран, о.Хоккайдо. Июль 1920 г.

Переход через океан на удивительном пароходе занял две недели, и в ночь с 31 июля на 1 августа 1920 года «Йомей Мару», преодолев почти пять тысяч миль, прибыл в порт Сан-Франциско.

3 августа вся первая страница газеты "San Francisco Chronicle" была занята фотографиями детей и персонала Красного Креста, сделанными на борту «Йомей Мару».

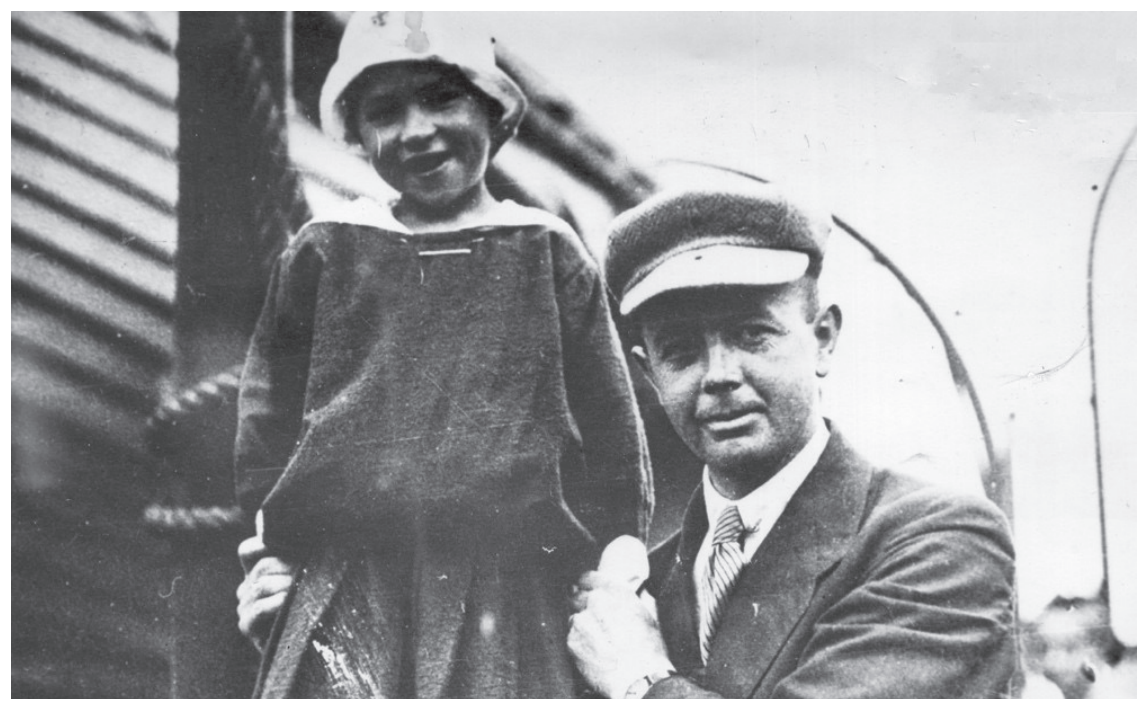

Райли Аллен с русской девочкой на борту «Йомей Мару» 
«ДЕТСКИЙ» КОРАБЛЬ БРОСАЕТ ЯКОРЬ В САН-ФРАНЦИСКО». Под таким заголовком был напечатан первый большой материал о петроградской детской колонии.

Военный форт Скотт недалеко от Сан-Франциско, спешно переоборудованный для приема необычных постояльцев, был готов к встрече гостей. Чистые койки с пологами от москитов, простая, но сытная еда, внимание волонтеров Красного Креста и огромного количества эмигрантов из России, стремившихся увидеться с детьми,-все это ожидало колонистов в форте. Экскурсии, концерты, встречи, подарки, гостинцы, приглашения семейств усыновить и удочерить желающих остаться в Соединенных Штатах обрушились на растерянных от обилия впечатлений ребят.

5 августа корабль покинул гостеприимный порт под приветственные крики собравшейся на пирсе толпы.

18 августа панамский порт Бальбоа заполнили жители, желавшие своими глазами увидеть «детский» корабль, который должен был пройти через знаменитые шлюзы Панамского канала, чтобы попасть в Атлантический океан и продолжить путешествие в его водах.

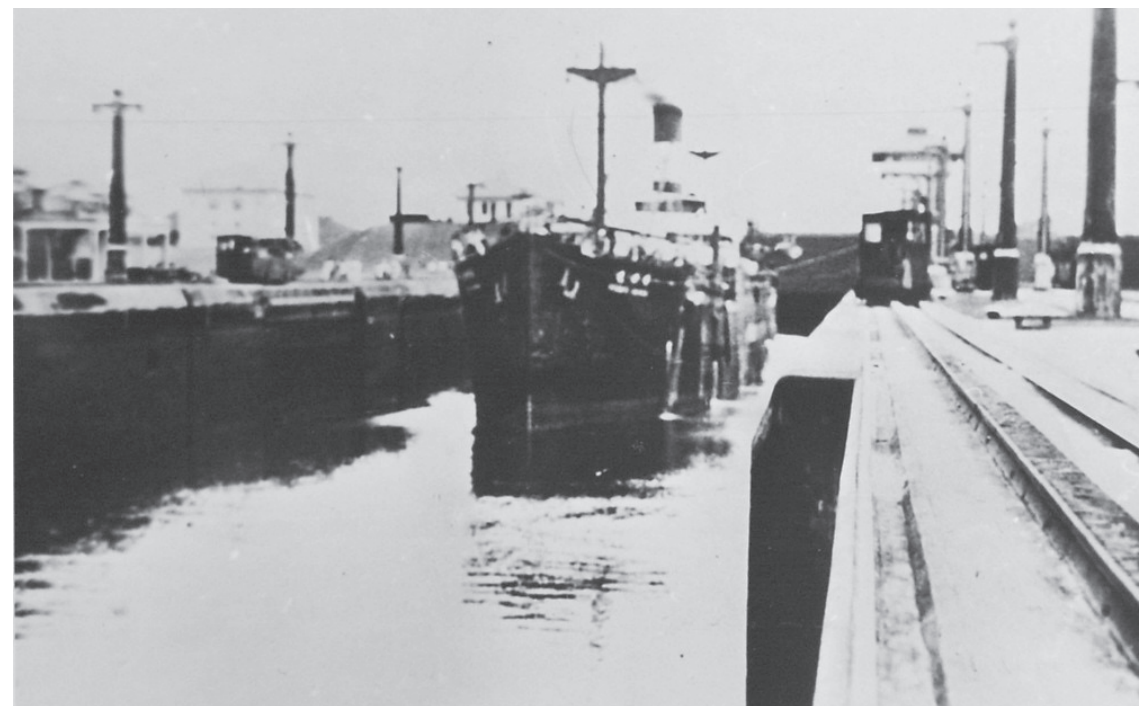

«Йомей Мару» в шлюзах Панамского канала. 1920 г.

Стояла изнуряющая жара, от которой жители северной российской столицы изрядно страдали. Понимая это и желая сделать для детей и персонала что-то приятное, местное отделение Красного Креста прислало на борт 50 галлонов отменного мороженого на картонных тарелках. Два ящика ананасов и 40 связок спелых бананов также оказались весьма уместными подарками.

И вот порт Бальбоа с добродушными панамцами позади, и «Йомей Мару» продолжает свое путешествие через два океана. 


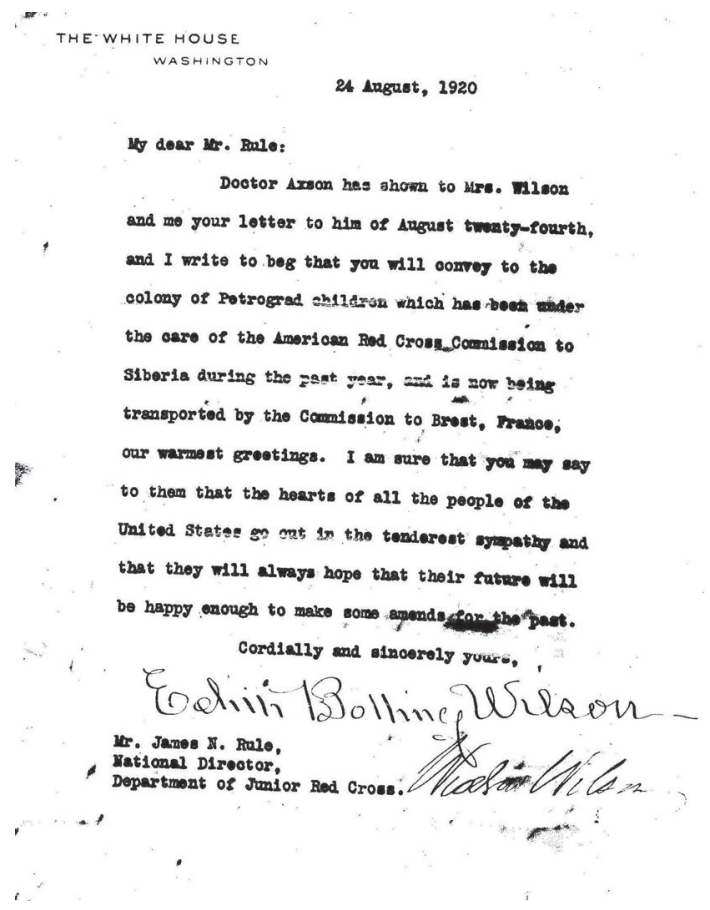

Письмо президента Вудро Вильсона с пожеланиями колонистам.
Райли Аллен, который отправился из Калифорнии в Нью- Йорк на поезде, уже ждет там своих подопечных, подготовив все что необходимо для их встречи. Форт Водсворт ${ }^{15}$ готов предоставить гостям свои казармы.

И снова восторженные толпы американцев и эмигрантов из России и Украины встречают японский корабль под американским флагом с русскими детьми на борту. И снова-встречи, концерты, подарки, экскурсии. Сам президент Вильсон, уже смертельно больной, подписывает свое фото и диктует обращение к петроградским детям. Обе копии-фото и письмо-в сотнях экземпляров размноженные в типографии Белого дома, раздаются всем колонистам. У некоторых эти замечательные сувениры чудом сохранятся, несмотря на страх перед репрессиями, войну, блокаду, эвакуацию.

Казалось бы все прекрасно. Дети полны впечатлений, они, как обычно, сыты, скромно, но чисто одеты и обуты, о них продолжают заботиться русские и американские воспитатели. Однако есть одно обстоятельство, которое омрачает настроение колонистов. Еще на пути в Нью-Йорк они узнают о решении главы Европейской комиссии Красного Креста полковника Роберта Олдса ${ }^{16}$ направить корабль с петроградскими детьми не непосредственно к берегам Балтики, как планировалось, а во Францию, где они должны остаться на неопределенное время. Объясняли этот неожиданный новый поворот в судьбах колонистов невозможностью отправить их в Советскую Россию, обстановка в которой была, по мнению Олдса, опасной для детей. Аллен, который с большой неохотой довел распоряжение Олдса до сведения колонистов, обещал, что как только обстановка изменится, ребят будут отправлять на родину небольшими группами по мере выяснения местонахождения и состояния их родителей. Ведь многие за это время могли покинуть Петроград

${ }^{15}$ Fort Wadsworth-форт на восточном берегу Staten Island.

16 Роберт Эдвин Олдс (Robert Edwin Olds ) (1875-1932)-американский дипломат, в 1919-21 гг был представителем Американского Красного Креста в Европе. 
и Россию, многие могли просто погибнуть в условиях голода, эпидемий и репрессий. Все эти, казалось бы, вполне резонные объяснения, не произвели никакого впечатления на колонистов. Желающих отправиться во Францию, которая успела проявить себя весьма недружелюбно по отношению к российским союзникам, не оказалось. Старшие колонисты, а вместе с ними и многие воспитатели, единодушно и резко выступили против «французского» варианта и, воспользовавшись поддержкой русскоязычной общественности в Нью-Йорке, в том числе непризнанного советского представителя Людвига Мартенса ${ }^{17}$, в конце концов, добились изменения решения.

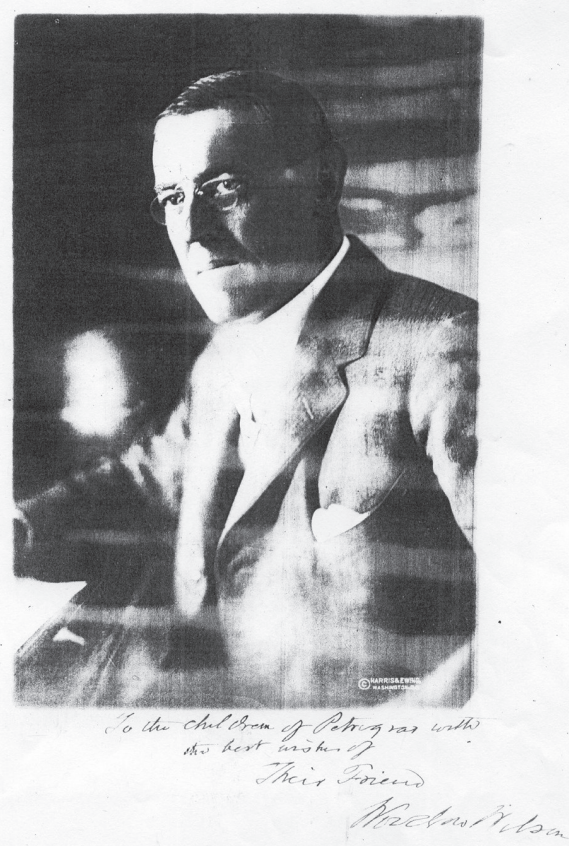

Портрет президента Вудро Вильсона с автографом.

Покинув гостеприимные Соединенные Штаты и достигнув Европы, «Йомей Мару» зашел во французский порт Брест всего лишь на несколько дней. Затем он взял курс к берегам Балтики и каждую минуту рискуя наскочить на одну из многочисленных морских мин, благодаря искусству лоцманов, сумел благополучно прибыть в порт Гельсингфорс

Финляндия, еще в декабре 1918 года, получившая независимость., оказалась единственной страной, которая разрешила судну войти в свои воды Однако в порту Гельсингфорс никто не встречал корабль с русскими детьми восторженными приветствиями, цветами и подарками. Его вообще никто не встречал. И сойти на берег было позволено лишь Аллену и нескольким его сотрудникам. Предстояли долгие и сложные переговоры с местными властями в поисках решения вопроса: что делать с пассажирами? Ведь уже все возможные сроки фрахта японского судна были превышены, и Красный Крест нес огромные расходы. Многие сотрудники Красного Креста, верные долгу, не покинули корабль у себя на родине, в Америке, а продолжили путь вместе со своими русскими подопечными. Но и они должны были рано или поздно вернуться домой, к своим собственным семьям.

17 Людвиг Карлович Мартенс (нем. Ludwig Christian Alexander Karl Martens) (1874-1948)- российский революционер немецкого происхождения, советский общественно-политический деятель, инженер, в 1919-1920 гг-официальный (непризнанный) представитель Советской России в США. 
Наконец, решение было найдено: колонистам позволят сойти на берег в порту Койвисто (нынешний город Приморск) из которого их переправят в бывший императорский санаторий «Халила» (сейчас санаторий «Сосновый Бор» на территории России), где они смогут разместиться в корпусах, предварительно переоборудованных для столь необычного контингента отдыхающих.

13 октября 1920 года закончился очередной этап удивительных приключений петроградских колонистов. Позади остались тысячи километров пути по суше и по морю. На всю жизнь врезались в память ни с чем не сравнимые впечатления.

Распрощавшись с командой и капитаном и в последний раз взглянув на «Йомей Мару», который три месяца служил им плавучим домом, колонисты отправились из Койвисто в Халила. До Петрограда было рукой подать-всего каких-нибудь 140 километров, а до границы-и того меньше.

Но теперь Аллену предстояло убедиться, что его подопечных действительно ждут в Петрограде, что у каждого есть хоть кто-то из родных, кто встретит и будет заботиться о нем. Однако почтовая связь с Советской Рос-

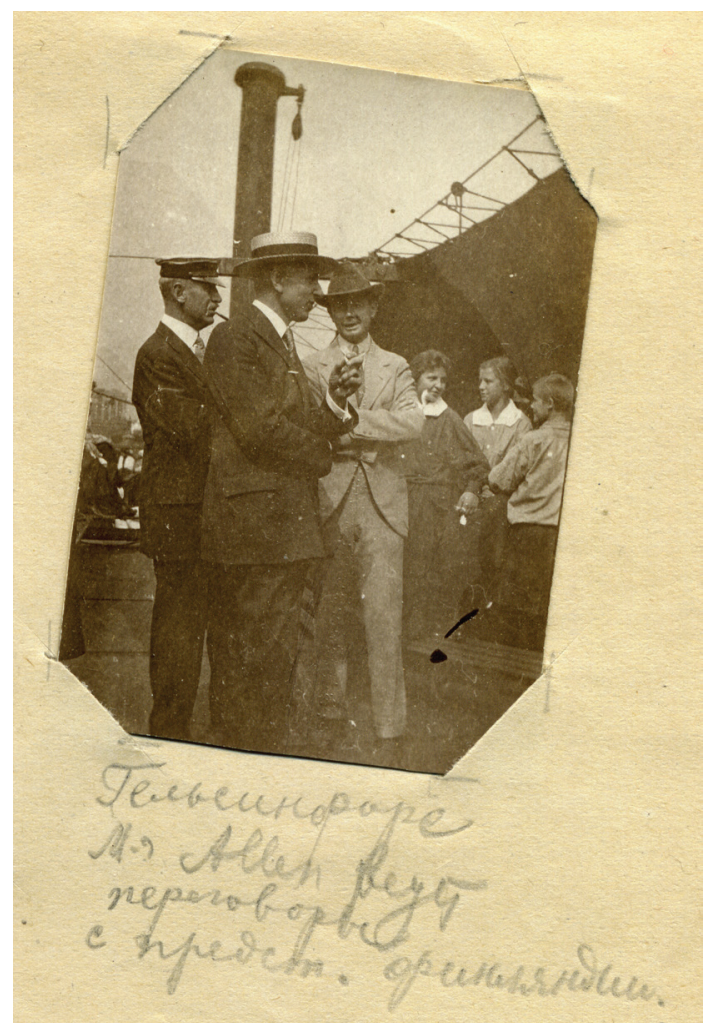

Райли Аллен ведет переговоры с финскими представителями в порту Гельсингфорс.

Страница из альбома колониста Н.Иванова. сией могла осуществляться лишь через Ревель (нынешний Таллинн, Эстония), а потому писем от родных ждали долго. Приходили они в разное время. И как только набиралась группа ребят, получивших подтверждение о том, что их ждут дома, их начинали готовить в путь. Зная об экономическом и продовольственном положении в Петрограде, американцы постарались обеспечить ребят хотя бы на первое время всем необходимым. Каждому был выдан специально сшитый мешок, набитый продовольствием и предметами первой необходимости. Каждый получил немного денег для того, чтобы купить что-то уже по своему усмотрению. У финских крестьян на рынке можно было купить и обменять все что угодно. 
Ребята не захотели остаться в долгу перед своими спасителями и друзьями. Каждый сотрудник Американского Красного Креста получил на память сувенир, сделанный руками колонистов. Несколько недель девочки и мальчики тайно вязали, шили и рисовали, выпиливали, вырезали и клеили. Это были подарки от всего сердца, которые они вручали Аллену и его сотрудникам с искренней любовью и благодарностью. Забыты были все конфликты, недоразумения и противоречия, никто не скрывал волнения и слез - ведь расставались навсегда. Даже самые маленькие понимали, чем они обязаны всем этим людям со значками Красного Креста на форменной одежде. И вот наступал день, когда очередная группа колонистов отправлялась вместе с Алленом на пограничный пункт в районе нынешнего поселка Белоостров ${ }^{18}$, где по предварительной договоренности с советскими властями, детей должны были по спискам переправлять через пограничную реку Сестру на российскую землю.

С волнением ступали на пограничный полуразрушенный мост колонисты, еще не зная, что их ждет впереди в их новой взрослой жизни. И их американские друзья не знали, что среди тех, с кем они прощаются, будущий организатор пионерского движения Валентин Цауне, будущий музыкант и известный музыкальный коллекционер Иван Семенов, будущий ленинградский композитор Виталий Запольский, будущий профессор, крупный ученый-биолог Николай Иванов, который поможет спасти многих горожан во время предстоящей блокады и убережет уникальную коллекцию семян, и даже будущий великий балетмейстер Леонид Якобсон и еще многие достойные граждане и прекрасные профессионалы, чьи судьбы и карьера могли бы

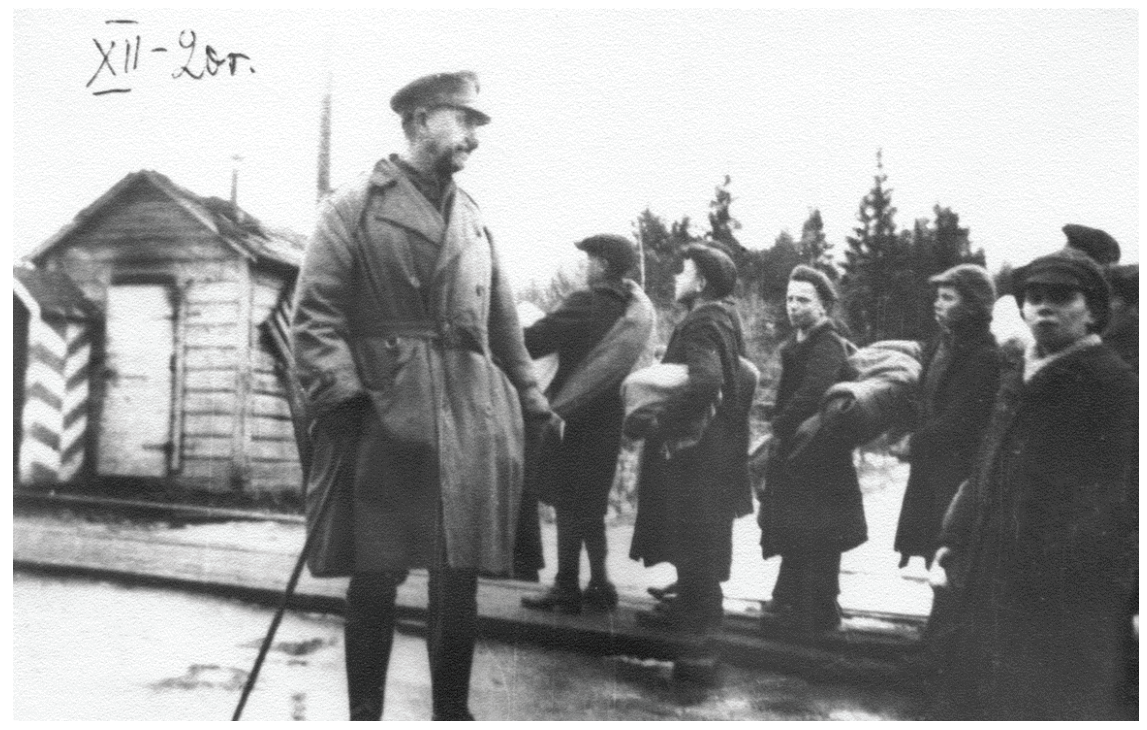

Группа колонистов на пограничном пункте вблизи поселка Белоостров. Осень 1920 г.

${ }^{18}$ В 1918-1940-м годах советско-финская граница проходила по реке Сестра, через посёлок Белоостров (Valkeasaari). 
быть совсем иными, если бы однажды добрый человек из Гонолулу Райли Аллен не взял на себя добровольную ответственность за их жизни...

В январе 1921 года последняя группа колонистов покинула Финляндию. Закончилась одна из самых удивительных одиссей в истории. Уехав в мае 1918 года с Финляндского вокзала на восток, 800 петроградских детей вернулись на тот же вокзал с запада, преодолев за два с половиной года более 36000 километров по суше и по морю и совершив, таким образом, настоящее кругосветное путешествие.

Райли Аллен вернулся в Гонолулу и прожил там большую плодотворную жизнь. Он умер очень пожилым человеком в конце 60-х годов ХХ века. Но еще долгое время его имя время от времени появлялось на страницах газеты, главным редактором которой он был многие годы после возвращения из России. Он сумел помочь еще очень многим детям разных национальностей и с разным цветом кожи. Он был великим гуманистом и интернационалистом. Знавшие его вспоминали, что он никогда и никому не позволял называть японцев презрительным словом “Јар”. Он всегда оставался верен принципам деятельности Красного Креста, которому отдал несколько лет жизни и большую часть своей души: помогать всем нуждающимся в помощи независимо от политической, религиозной, расовой и национальной принадлежности.

Аллен больше никогда не встречался со своими петроградскими подопечными. Но каждый из них хранил память о нем до конца жизни. Ведь если бы не этот человек, кто знает, как бы сложились их судьбы? Смогли бы их дети, внуки и правнуки собраться вместе, как собрались они в январе 2007 года, чтобы почтить память не только своих родных-бывших мальчиков и девочек из Петроградской детской питательной колонии, но и тех, кто когда-то протянули им руку помощи, и в первую очередь-гражданина Соединенных Штатов Америки и гражданина мира Райли Х. Аллена.

$* * *$

Нет сомнения, что эта история принадлежит не только потомкам спасённых и спасителей. Все происходившие события и люди, участвовавшие в них, достойны того, чтобы стать темой серьёзных исследований - историков разных направлений, представителей разных стран, в особенностистран-участниц одиссеи. Однако, как это ни странно, столь удивительный эпизод практически не нашёл своего профессионального исследователя до сих пор. Во всяком случае, нам об этом ничего не известно. В нашем распоряжении есть сборник Делаверские записки ${ }^{19}$ в которых в 1949 году был опубликован материал, написанный Джейн Сван, выпускницей Пенсильванского университета и основанный по большей части на рассказах и свидетельствах ее мужа, известного американского музыковеда Альфреда Джулиуса Свана, которому довелось участвовать в спасении петроградских

${ }^{19}$ An Episode in the Great Russian Revolution:the Children's Colonies in Siberia by Jane B.Swan and Walter Kirchner. Delawere Notes. University of Delawere.1949. 
детей в 1918-19 гг. Впоследствии, Джейн Сван вновь занялась этой историей и описала ее намного более подробно в своей книге ${ }^{20}$, работая над которой она посетила некоторых бывших колонистов в Ленинграде и взяла у них интервью. В 1965 году вышла книга Флойда Миллера ${ }^{21}$, основанная на воспоминаниях одной из сотрудниц миссии Американского Красного Креста в России Ханны Кэмпбелл. Однако эту книгу никак нельзя считать поностью документальной.

В период перестройки и в постсоветский период вновь возник интерес к этой малоизвестной странице российско-американских отношений. Тогда вышел роман Владимира Липовецкого 22 и документальная повесть автора этой статьи ${ }^{23}$. Появился ряд статей в газетах и журналах, радио- и телевизионные передачи. В 2018 году ограниченным тиражом издан перевод на русский язык уникальных воспоминаний капитана сухогруза «Йомей Мару» Мотодзи Каяхара ${ }^{24}$. Однако ни одно из названных изданий нельзя считать в полной мере историческим исследованием, так как авторы не являются профессиональными историками и ставили перед собой в основном гуманитарные и образовательные задачи. Тем не менее их работы, а также большой корпус дневников, воспоминаний, документов и фотографий, сохраненных в самые трудные и опасные времена участниками событий ${ }^{25}$, могли бы послужить хорошей основой для серьезной работы историков, так как события столетней давности, кратко описанные в этой статье, требуют гораздо более глубокого и всестороннего изучения и анализа.

${ }^{20}$ The Lost Children. A Russian Odyssey by Jane B.Swan. Pensilvania. 1989.

${ }^{21}$ Wild Children of the Urals by Floyd Miller. New York. 1965.

${ }^{22}$ В.Липовецкий. Ковчег детей или Невероятная одиссея. СПб, Азбука-классика. 2005.

${ }^{23}$ О.Молкина. Над нами Красный Крест. СПб,Остров.2005, 2007(второе издание).

${ }^{24}$ Мотодзи Каяхара. Малоизвестная история времен Красной революции. Записки о перевозке российской детской колонии. Авторское издание. Япония. 1934. Перевод на русский язык. СПб, 2018. Издание осуществлено на средства Сообщества потомков участников событий и партнеров Проекта «Над нами Красный Крест» и не является коммерческим. Текст доступен на сайте: http://www.petrograd-kids-odyssey. ru/files/books/book_japan.pdf.

${ }^{25}$ Наиболее полная информация об истории спасения петроградских детей, включающая публикации разных лет, фотографии, документы, видеозаписи, а также отражающая многолетнюю работу Сообщества потомков участников событий в рамках Проекта международной солидарности «Над нами Красный Крест». представлена на сайте www.petrograd-kids-odyssey.ru, созданном в 2016 году при поддержке Генерального консульства США в Санкт-Петербурге. 